\title{
JNPH
}

Volume 7 No. 2 (Oktober 2019)

(C) The Author(s) 2019

\section{FAKTOR-FAKTOR YANG BERHUBUNGAN DENGAN PERILAKU MENCUCI TANGAN MENGGUNAKAN SABUN PADA SISWA DI SD NEGERI 08 LUBUK LINGGAU}

\section{FACTORS ASSOCIATED WITH HANDWASHING WITH SOAP OF STUDENTS IN SD NEGERI 08 LUBUK LINGGAU}

\author{
SANTOSO UJANG EFFENDI, RINA APRIANTI, SARAH FUTUBELA \\ PRODI KESEHATAN MASYARAKAT STIKES TRI MANDIRI SAKTI BENGKULU \\ JL. HIBRIDA RAYA NO. 03 KELURAHAN SIDOMULYO KOTA BENGKULU 38229 \\ Email: santos_ue@yahoo.com
}

\begin{abstract}
ABSTRAK
Cuci tangan pakai sabun yang dipraktikkan secara tepat dan benar merupakan cara termudah dan efektif untuk mencegah terjangkitnya penyakit infeksi, seperti Cholera, Hepatitis A, dan ISPA. Penelitian ini bertujuan untuk mempelajari faktor-faktor yang berhubungan dengan perilaku mencuci tangan menggunakan sabun pada siswa di SD Negeri 08 Lubuklinggau. Penelitian ini menggunakan jenis Survey Analitik dengan desain Cross Sectional. Populasi dalam penelitian ini adalah siswa kelas IV dan V SD Negeri 08 Tahun Ajaran 2017/2018 Lubuklinggau sebanyak 144 siswa. Sampel diambil dengan menggunakan teknik Proportional Random Sampling. Jumlah sampel dalam penelitian ini adalah 106 siswa .Pengambilan data dilakukan dengan mengisi kuesioner kepada responden..Analisis data dilakukan dengan uji Chi-Square $\left(\chi^{2}\right)$ dan Contingency Coefficient (C). Hasil penelitian menunjukkan bahwa terdapat 56 siswa $(52,8 \%)$ memiliki pengetahuan baik, 61 siswa yang memiliki sikap favourable $(57,5 \%), 60$ siswa $(56,6 \%)$ memiliki peran orang tua baik, dan 91 siswa $(85,8 \%)$ memiliki perilaku mencuci tangan menggunakan sabun baik. Ada hubungan yang signifikan antara pengetahuan dengan perilaku mencuci tangan menggunakan sabun dengan kategori keeratan hubungan lemah, tidak ada hubungan yang signifikan antara sikap dengan perilaku mencuci tangan menggunakan sabun, dan tidak ada hubungan antara peran orang tua dengan perilaku mencuci tangan menggunakan sabun. Diharapkan bagi sekolah untuk memberikan edukasi tentang perilaku mencuci tangan dan menyediakan fasilitas untuk menerapkan perilaku mencuci tangan.
\end{abstract}

Kata Kunci: perilaku mencuci tangan, pengetahuan, peran orang tua, sikap, siswa

\begin{abstract}
Washing hands with soap that is practiced appropriately and correctly is the easiest and effective way to prevent infectious diseases such as cholera, ISPA, and hepatitis A. The aim of This study was to investigate the factors related to the use of soap in students at Lubuklinggau State Elementary School 08. This research used Analytical Survey type with Cross Sectional design. The population in this study were grade IV and V students of SD Negeri 08 in the academic year 2017/2018 Lubuklinggau with 144 students. Samples were taken using
\end{abstract}


Proportional Random Sampling technique, the number of samples in this study were 106 students. Data is collected by filling out questionnaires to respondents. Data analysis was performed with the Chi-Square test $\left(\chi^{2}\right)$ and Contingency Coefficient $(\mathrm{C})$. The results of the study showed that 56 students $(52.8 \%)$ had good knowledge, 61 students who had favorable attitudes $(57.5 \%), 60$ students $(56.6 \%)$ had roles good parents and 91 students $(85.8 \%)$. There was a significant relationship between knowledge and research related to soap with the category of closeness of weak relationships, there was no significant relationship between relationships with the help of hands use soap, and there is no relationship between the role of parents with the interaction of holding soap. The results of this study are expected to schools to give education about hand washing behavior and give facilities for applying hand washing behavior.

\section{Keywords: attitude, hand washing behavior, knowledge, attitude, role of student's parents, students}

\section{PENDAHULUAN}

Di Indonesia cuci tangan belum menjadi budaya yang dilakukan oleh masyarakat luas. Dalam kehidupan sehari-hari, banyak yang mencuci tangan hanya dengan air sebelum makan, cuci tangan dengan sabun justru dilakukan sesudah makan (Kemenkes RI, 2014). Penelitian menunjukkan bahwa saat tangan yang terkontaminasi baik oleh kotoran manusia, binatang, ataupun cairan tubuh tidak dicuci dengan sabun akan berpotensi memindahkan bakteri, virus, maupun parasit pada orang lain (Fewtrell et al., 2005).

Banyak penyakit yang bisa bersarang dalam tubuh bila lalai mencuci tangan, misalnya tifus, infeksi jamur, polio, disentri, diare, kolera, cacingan, ISPA dan hepatitis A. Sebagai populasi yang rentan terserang penyakit, 3.5 juta anak-anak diseluruh dunia meninggal setiap tahunnya karena penyakit ISPA dan diare dan menjadikannya penyebab utama kematian anak (Priyoto, 2015).

Cuci tangan pakai sabun sebagai upaya preventif dalam melindungi diri dari berbagai penyakit menular. Cuci tangan menggunakan sabun dapat kita lakukan pada waktu-waktu berikut: sebelum menyiapkan makanan, sebelum dan sesudah makan, setelah BAK dan $\mathrm{BAB}$, setelah membuang ingus, setelah membuang dan atau menangani sampah, kemudian setelah bermain/memberi makan/memegang hewan, serta setelah batuk atau bersin pada tangankita (Desiyanto \& Djannah, 2013).
Cuci tangan pakai sabun yang dipraktikan secara tepat dan benar merupakan cara termudah dan efektif untuk mencegah berjangkitnya penyakit. Mencuci tangan dengan air dan sabun dapat lebih efektif menghilangkan kotoran dan debu secara mekanis dari permukaan kulit dan secara bermakna mengurangi jumlah mikroorganisme penyebab penyakit seperti virus, bakteri dan parasit lainnya pada kedua tangan. Mencuci tangan dengan menggunakan air dan sabun dapat lebih efektif membersihkan kotoran dan telur cacing yang menempel pada permukaan kulit, kuku dan jari-jari pada kedua tangan (Desiyanto \& Djannah, 2013).

Anak-anak selalu menjadi pihak yang paling rentan terhadap penyakit sebagai akibat perilaku yang tidak sehat dan sanitasi yang buruk, padahal anak-anak merupakan aset bangsa yang paling berperan untuk generasi yang akan datang. Anak-anak juga merupakan penyampai pesan yang penting pada keluarga dan lingkungan tempat tinggalnya. Untuk memutuskan mata rantai penyebaran penyakit, pemberian edukasi tentang pola hidup sehat kepada anak-anak penting untuk dilakukan karena anak-anak banyak menghabiskan banyak waktunya di sekolah (Ma'rifah \& Krisdian, 2015).

Derajat kesehatan anak pada saat ini belum dapat dikatakan baik, karena masih ada permasalahan kesehatan khususnya pada anak usia sekolah. Pendidikan kesehatan melalui anak-anak sekolah sangat efektif untuk 
merubah perilaku dan kebiasaan sehat umumnya. Perilaku seseorang dapat dipengaruhi oleh faktor-faktor seperti pengetahuan, sikap, dan peran lingkungan (Notoatmodjo, 2010).

Mulai masuk sekolah merupakan hal penting bagi tahap perkembangan anak. Banyak masalah kesehatan terjadi pada anak usia sekolah, seperti misalnya pelaksanaan Perilaku Hidup Bersih dan Sehat (PHBS) seperti menggosok gigi dengan baik dan benar, mencuci tangan menggunakan sabun, karies gigi, kecacingan, kelainan refraksi/ketajaman penglihatan dan masalah gizi. Anak usia sekolah merupakan sasaran yang strategis untuk pelaksanaan program kesehatan, karena selain jumlahnya yang besar, mereka juga merupakan sasaran yang mudah dijangkau karena terorganisir dengan baik (Kemenkes RI, 2014). Sekolah memiliki peran penting dalam mendidik dan mendorong kebiasaan cuci tangan sejak usia dini karena kebiasaan mencuci tangan yang dipelajari di sekolah dapat bertahan seumur hidup (Global Hand washing Day, 2008). Selain itu, anak-anak juga merupakan caloncalon agen perubah untuk lingkungan sekitarnya (Kemenkes RI, 2014).

Menurut hasil Riskesdas tahun 2013 diketahui bahwa berdasarkan analisis kecenderungan secara rerata nasional, terdapat peningkatan proporsi penduduk berperilaku cuci tangan secara benar pada tahun 2013 (47,0\%) dibandingkan tahun 2007 $(23,2 \%)$. Peningkatan tertinggi proporsi penduduk berperilaku cuci tangan benar terjadi di Bangka Belitung dengan besar kenaikan 35,0 persen $(20,6 \%$ pada tahun 2007 menjadi 55,6\% pada 2013) dan lima provinsi terendah adalah Sumatera Barat $(29,0 \%)$, Papua (29,5\%), Kalimantan Selatan (32,3\%), Sumatera Utara $(32,9 \%)$ dan Aceh $(33,6 \%)$. Proporsi penduduk umur $\geq 10$ tahun yang berperilaku benar dalam cuci tangan di Sumatera Selatan 45,3\% (Kemenkes RI, 2018).

Berdasarkan survei awal pada tanggal 21 Desember 2018 yang dilakukan oleh peneliti di SD Negeri 08 Lubuklinggau terhadap 15 orang siswa kelas IV berjumlah 8 siswa dan V berjumlah 7 siswa, dengan metode wawancara yang berisi tentang Pengetahuan mencuci tangan, cara mencuci tangan yang di lakukan siswa, siswa sudah atau belum mengetahui apa akibat jika tidak melakukan cuci tangan menggunakan sabun, manfaat mencuci tangan, sikap siswa terhadap mencuci tangan menggunakan sabun setelah jam istirahat dan berolahraga, peran orang tua yang mengajarkan siswa terhadap mencuci tangan menggunakan sabun. Diperoleh hasil bahwa terdapat 11 siswa yang saya tanyakan memiliki pengetahuan yang kurang tentang pentingnya mencuci tangan menggunakan sabun. Saat dilakukan wawancara dengan 4 siswa lainnya memiliki kebiasaan kadangkadang tidak mencuci tangan saat akan makan, serta belum bisa melakukan 6 langkah cuci tangan yang benar.

Hasil observasi pelaksanaan program UKS di awal tahun 2017-2018 ini belum banyak kegiatan yang dilaksanakan, sehingga cukup banyak kasus penyakit yang ditemukan pada siswa terutama di SD 08 yaitu 2 orang siswa pada bulan desember 2017 dirawat dengan diagnosa penyakit tipus, dalam 3 bulan terakhir ini beberapa siswa izin tidak masuk sekolah dengan alasan sakit yang terbanyak adalah diare 10 orang dari 20 siswa yang sakit.

Rumusan masalah penelitian ini adalah "Faktor-faktor apa saja yang berhubungan dengan perilaku mencuci tangan menggunakan sabun pada siswa di SD Negeri 08 Lubuklinggau?". Tujuan penelitian ini adalah untuk mempelajari faktor-faktor apa saja yang berhubungan dengan perilaku mencuci tangan menggunakan sabun pada siswa di SD Negeri 08 Lubuklinggau.

\section{METODE PENELITIAN}

Penelitian dilaksanakan di SD Negeri 08 Lubuklinggau pada 16-18 Juni 2019. Jenis penelitian adalah Survey Analitik dengan desain Cross Sectional. Populasi dalam penelitian ini adalah siswa kelas IV dan V SD Negeri 08 Tahun Ajaran 2017/2018 
Lubuklinggau sebanyak 144 siswa. Sampel diambil dengan menggunakan teknik Proportional Random Sampling. Jumlah sampel dalam penelitian ini adalah 106 siswa. Jenis data yang digunakan adalah data primer dan data sekunder. Pengambilan data dilakukan dengan mengisi kuesioner kepada responden. variabel independent adalah pengetahuan, sikap, orang tua dan variabel dependent adalah perilaku mencuci tangan dengan sabun). Data dianalisis secara univariat dan bivariat. Analisis data dilakukan dengan uji Chi-Square $\left(\chi^{2}\right)$ dan Contingency Coefficient (C).

\section{HASIL PENELITIAN}

\section{Analisis Univariat}

Analisis univariat bertujuan untuk menggambarkan distribusi frekuensi dari variabel independent dan variabel dependent . Hasil analisis univriat dapat dilihat pada table berikut :

\section{a. Distribusi Frekuensi Pengetahuan siswa di SD Negeri 08 Kota Lubuklinggau}

Tabel 1. Distribusi Frekuensi Pengetahuan di SD Negeri 08 Kota Lubuklinggau

\begin{tabular}{cccc}
\hline No & Pengetahuan & Frekuensi & Persentase (\%) \\
\hline 1 & Kurang & 16 & 15,1 \\
\hline 2 & Cukup & 34 & 32,1 \\
\hline 3 & Baik & 56 & 52,8 \\
\hline & Total & 106 & 100,0 \\
\hline
\end{tabular}

Berdasarkan Tabel 1 di atas diketahui bahwa dari 106 siswa, terdapat $16(15,1 \%)$ siswa yang memiliki pengetahuan kurang, terdapat 34 siswa $(32,1 \%)$ yang memiliki pengetahuan cukup dan siswa yang memiliki pengetahuan baik sebanyak 56 siswa $(52,8 \%)$.

\section{b. Distribusi Frekuensi Sikap siswa di SD Negeri 08 Kota Lubuklinggau}

Tabel 2. Distribusi Frekuensi Sikap di SD Negeri 08 Kota Lubuklinggau

\begin{tabular}{cccc}
\hline No & Sikap & Frekuensi & Persentase (\%) \\
\hline 1 & Unfavorable & 45 & 42,0 \\
\hline 2 & Favorable & 61 & 58,0 \\
\hline & Total & 106 & 100,0 \\
\hline
\end{tabular}

Berdasarkan Tabel 2 di atas diketahui bahwa dari 106 siswa di SD Negeri 08 Kota Lubuklinggau. terdapat 45 siswa bersikap unfavorable $(42,0 \%)$, dan 61 siswa bersikap favorable $(58,0 \%)$.

\section{c. Distribusi Frekuensi Peran Orang Tua di SD Negeri 08 Kota Lubuklinggau}

Tabel 3. Distribusi Frekuensi Peran Orang Tua di SD Negeri 08 Kota Lubuklinggau

\begin{tabular}{cccc}
\hline No & Peran Orang Tua & Frekuensi & Persentase (\%) \\
\hline 1 & $\begin{array}{c}\text { Tidak } \\
\text { Mendukung }\end{array}$ & 46 & 43,0 \\
\hline 2 & Mendukung & 60 & 57,0 \\
\hline & Total & 106 & 100,0 \\
\hline
\end{tabular}

Berdasarkan Tabel 3 diketahui bahwa dari 104 siswa di SD Negeri 08 Kota Lubuklinggau, terdapat peran orang tua siswa tidak mendukung $46(43,0 \%)$, terdapat peran orang tua siswa $60(57,0 \%)$ mendukung.

\section{d. Distribusi Frekuensi Perilaku Mencuci Tangan Menggunakan Sabun di SD Negeri 08 Kota Lubuklinggau}

Tabel 4. Distribusi Frekuensi Perilaku Mencuci Tangan Menggunakan Sabun di SD Negeri 08 Kota Lubuklinggau

\begin{tabular}{cccc}
\hline No & $\begin{array}{c}\text { Perilaku } \\
\text { Mencuci } \\
\text { Tangan }\end{array}$ & Frekuensi & Persentase (\%) \\
\hline 1 & Tidak Baik & 15 & 14,0 \\
\hline 2 & Baik & 91 & 86,0 \\
\hline & Total & 106 & 100,0 \\
\hline
\end{tabular}

Berdasarkan Tabel 4 diketahui bahwa dari 106 siswa di SD Negeri 08 Kota Lubuklinggau, terdapat 15 siswa (14\%) memiliki perilaku mencuci tangan dengan sabun yang tidak baik dan 91 siswa $(86 \%)$ 
memiliki perilaku mencuci tangan dengan sabun yang baik.

\section{Analisis Bivariat}

Analisis ini dilakukan untuk mengetahui hubungan antara variabel independent dan variabel dependent di SD Negeri 08 Kota Lubuklinggau.

a. Hubungan Pengetahuan dengan Perilaku Mencuci Tangan Menggunakan Sabun di SD Negeri 08 Kota Lubuklinggau

Tabel 5. Hubungan Pengetahuan dengan Perilaku Mencuci Tangan dengan Menggunakan Sabun di SD Negeri 08 Kota Lubuklinggau

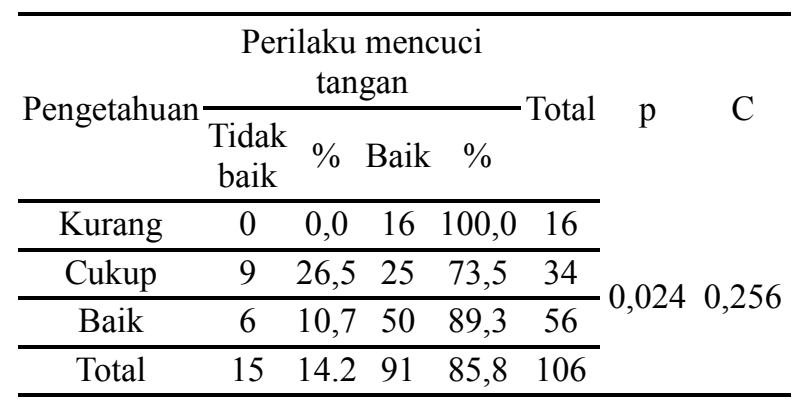

Berdasarkan Tabel 5 diatas dapat diketahui bahwa dari total 106 siswa terdapat 16 siswa yang pengetahuan kurang dengan perilaku mencuci tangan yang baik. Dari 34 siswa yang pengetahuan cukup terdapat 9 siswa yang perilaku mencuci tangan tidak baik, dan 25 siswa pengetahuan cukup dengan perilaku mencuci tangan yang baik. dari 56 siswa yang memiliki pengetahuan mencuci tangan yang baik terdapat 6 siswa yang perilaku mencuci tangan nya tidak baik, dan 50 siswa yang berperilaku mencuci tangan yang baik. Di SD Negeri 08 Kota Lubuklinggau.

Untuk mengetahui hubungan pengetahuan dengan perilaku mencuci tangan menggunakan sabun di SD Negeri 08 Kota lubuklinggau.digunakan uji Chi-Square (Pearson Chi-Square). Hasil uji Pearson Chi-Square didapat nilai asymp.sig (p) = 0,024 . Karena nilai $\mathrm{p}<0,05$ maka Ho ditolak
Ha diterima jadi ada hubungan yang signifikan antara pengetahuan dengan perilaku mencuci tangan di SD Negeri 08 Kota Lubuklinggau.Untuk mengetahui keeratan hubungan pengetahuan dengan perilaku mencuci tangan menggunakan sabun di SD Negeri 08 Kota Lubuklinggau menggunakan Contingency Coefficient di dapat nilai $\mathrm{C}=0,256$ karena nilai tersebut tidak terlalu jauh dengan $\mathrm{Cmax}=0,707$ maka hubungan pengetahuan dengan perilaku mencuci tangan menggunakan sabun di SD Negeri 08 Kota Lubuklinggau di kategorikan Lemah.

b. Hubungan Sikap dengan Perilaku Mencuci Tangan Menggunakan Sabun di SD Negeri 08 kota lubuklinggau di SD Negeri 08 Kota Lubuklinggau

Tabel 6. Hubungan Sikap dengan Perilaku Mencuci Tangan Menggunakan Sabun di SD Negeri 08 Kota Lubuklinggau

\begin{tabular}{|c|c|c|c|c|c|c|c|}
\hline \multirow{3}{*}{ Sikap } & \multicolumn{4}{|c|}{$\begin{array}{c}\text { Perilaku Mencuci } \\
\text { Tangan }\end{array}$} & \multirow{2}{*}{ Total } & \multirow{3}{*}{$\mathrm{p}$} & \multirow{3}{*}{$\mathrm{C}$} \\
\hline & \multicolumn{2}{|c|}{$\begin{array}{l}\text { Tidak } \\
\text { Baik }\end{array}$} & \multicolumn{2}{|c|}{ Baik } & & & \\
\hline & $\mathrm{F}$ & $\%$ & $\mathrm{~F}$ & $\%$ & $F$ & & \\
\hline Unfavorable & 5 & 11,1 & 40 & 88,9 & 45 & & \\
\hline Favorable & 10 & 16,4 & 51 & 83,6 & 61 & 0,625 & 0,075 \\
\hline Total & 15 & 14,2 & 91 & 85,8 & 106 & & \\
\hline
\end{tabular}

Berdasarkan Tabel 6 dapat diketahui bahwa dari total 106 siswa terdapat 45 siswa yang memiliki sikap unfavorable 5 tidak baik dan terdapat 40 siswa yang perilaku mencuci tangan nya baik, sedangkan 61 siswa yang termasuk dalam favorable terdapat 10 siswa yang perilaku mencuci tangan nya tidak baik, dan 51 siswa lainnya termasuk kategori perilaku mencuci tangan yang baik di SD Negeri 08 Kota Lubuklinggau. Untuk mengetahui hubungan sikap dengan Perilaku Mencuci tangan Menggunakan sabun di SD Negeri 08 Kota Lubuklinggau digunakan uji Chi-Square (Continuity Correction). Hasil uji Continuity Correction di dapat dengan nilai asymp.sig $(\mathrm{p})=0,625$. Karena nilai $\mathrm{p}>0,05$ 
maka tidak ada hubungan yang signifikan antara sikap dengan perilaku mencuci tangan menggunakan sabun di SD Negeri 08 Kota Lubuklinggau.

C. Hubungan Peran Orang Tua Dengan Perilaku Mencuci Tangan Menggunakan Sabun Di SD Negeri 08 Kota Lubuklinggau

Tabel 7. Hubungan Peran Orang tua dengan Perilaku Mencuci Tangan Menggunakan Sabun di SD Negeri 08 Kota Lubuklinggau

\begin{tabular}{|c|c|c|c|c|c|}
\hline \multirow{3}{*}{$\begin{array}{c}\text { Peran Orang } \\
\text { Tua }\end{array}$} & \multicolumn{2}{|c|}{$\begin{array}{c}\text { Perilaku Mencuci } \\
\text { Tangan }\end{array}$} & \multirow{3}{*}{ Total } & \multirow{3}{*}{$\mathrm{p}$} & \multirow{3}{*}{$\mathrm{C}$} \\
\hline & $\begin{array}{l}\text { Tidak } \\
\text { Baik }\end{array}$ & Baik & & & \\
\hline & $\mathrm{F}$ & $\%$ & & & \\
\hline
\end{tabular}

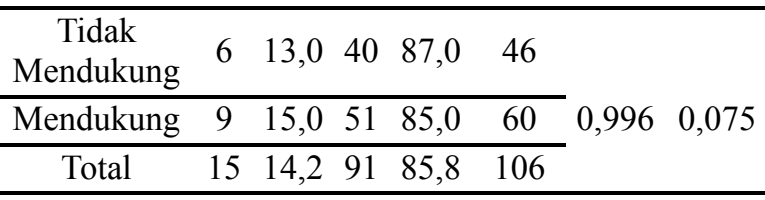

Berdasarkan Tabel 7 dapat diketahui bahwa dari total 106 siswa terdapat 46 peran orang tua siswa yang tidak mendukung, terdapat 6 peran orang tua siswa yang tidak baik dan 40 peran orang tua siswa yang baik. Sedangkan dari total 60 siswa yang mendukung terdapat peran orang tua siswa 9 yang tidak baik dan 51 peran orang tua siswa yang baik di SD Negeri 08 Kota Lubuklinggau.

Untuk mengetahui hubungan peran orang tua dengan Perilaku Mencuci tangan Menggunakan sabun di SD Negeri 08 Kota Lubuklinggau digunakan uji Chi-Square (Continuity correction). Hasil uji Continuity correction didapat dengan nilai asymp.sig (p) $=(0,996)$. Karena nilai $\mathrm{p}>0,05$ maka tidak ada hubungan yang signifikan antara sikap dengan perilaku mencuci tangan menggunakan sabun di SD Negeri 08 Kota Lubuklinggau.

\section{PEMBAHASAN}

\section{Analisis Univariat}

a. Gambaran Pengetahuan perilaku mencuci tangan menggunakan sabun di SD Negeri 08 Kota Lubuklinggau

Berdasarkan hasil penelitian yang dilakukan oleh peneliti di SD Negeri 08 Kota Lubuklinggau dari 106 Siswa, terdapat 16 siswa yang memiliki pengetahuan kurang $(15,1 \%)$, terdapat 34 siswa yang memiliki pengetahuan cukup $(32,1 \%)$ dan siswa yang memilki pengetahuan baik $56(52,8 \%)$.

Pada saat peneliti melakukan penelitian di SD Negeri 08 Kota Lubuklinggau Terdapat siswa yang memiliki pengetahuan kurang bisa di lihat dari hasil kuesioner pengetahuan dengan skor nilai kuesioner $<56 \%$ maka termasuk pengetahuan kurang, bahwa pengetahuan yang kurang ini terlihat dari jawaban kuesioner banyak siswa yang tidak mengetahui mencuci tangan menggunakan apa, penyakit apa saja yang terjadi jika tidak mencuci tangan, langkah mencuci tangan, dan berapa lama untuk waktu untuk mencuci tangan.

Dari hasil kuesioner pengetahuan cukup bisa dilihat dari hasil kuesioner pengetahuan dengan skor nilai kuesioner 56\%-75\% maka termasuk pengetahuan cukup, bahwa pengetahuan yang cukup ini terlihat dari jawaban kuesioner banyak siswa yang tidak terlalu memahami betul bagian mana saja langkah awal dari cuci tangan yang benar, dan langkah-langkah cuci tangan sesuai dari WHO. Hasil kuesioner yang menunjukkan pengetahuan baik dapat dilihat dari skor nilai pengetahuan jika nilai skor $76 \%-100 \%$ maka termasuk pengetahuan baik, dapat dilihat dari jawaban kuesioner yang sudah memahami mengenai cara mencuci tangan yang baik dan benar, penyakit apa saja yang dapat di timbulkan bila siswa tidak mencuci tangan, mereka yang berpengetahuan baik akan memperlihatkan keahliannya dalam mempraktekkan cara mencuci tangan yang baik dan benar ketika saya sedang mengawasi mereka dalam mengerjakan kuesioner. 
Hal ini sesuai teori Notoatmodjo (2010) Pengetahuan yang dimiliki oleh seseorang juga dipengaruhi oleh informasi. semakin banyak orang menggali informasi baik dari media cetak maupun media elektronik maka pengetahuan yang dimiliki semakin meningkat.

\section{b. Gambaran Sikap perilaku mencuci tangan menggunakan sabun di SD Negeri 08 Kota Lubuklinggau}

Berdasarkan hasil penelitian yang dilakukan oleh peneliti di SD Negeri 08 Kota Lubuklinggau dari 106 Siswa, terdapat siswa yang memiliki sikap unfavorable $(42,4 \%)$ dan favorable $(57,5 \%)$. Berdasarkan hasil kuesioner tersebut terlihat bahwa sebagian besar sikap perilaku siswa dalam mencuci tangan menggunakan sabun unfavorable, pernyataan negatif siswa yang bersifat tidak mendukung yaitu setelah cuci tangan harus dikeringkan dengan handuk/tisu mereka mengatakan bisa saja di keringkan melalui celana, dan siswa melakukan pernyataan bahwa sesudah memegang hewan peliharaan cuci tangan juga seperti keberatan untuk mencuci tangan selalu di setiap sebelum dan setelah kegiatan yang dilakukan sedangkan dari hasil kuesioner favorable yaitu kalimat yang bersifat mendukung atau memihak pada objek dinyatakan $1=$ mendukung jika skor jawaban $>23$ Median.

Berdasarkan hasil kuesioner tersebut terlihat bahwa sikap perilaku siswa favorable hal ini dapat dinyatakan mendukung di lihat dalam mengenai pernyataan yang siswa buat seperti misalnya sesudah buang air besar harus cuci tangan, sesudah membuang sampah mencuci tangan, mencuci tangan harus menggunakan air mengalir dan sabun, dan sebelum dan sesudah makan cuci tangan. saat peneliti setelah melakukan penelitian terlihat sebagian dari siswa mencuci tangannya ketika hendak makan di kantin dan ada juga yang membuang sampah dari yang mereka makan langsung mencuci tangan di tempat fasilitas yang sudah disediakan dari pihak sekolah.
Sikap merupakan suatu tanggapan seseorang terhadap ransangan yang diterimanya. Sikap adalah reaksi yang masih tertutup dari seseorang dan belum mengarah pada terjadinya suatu tindakan (Notoatmodjo, 2010). Menurut Azwar (2009), sikap terdiri dari tiga komponen, yaitu kognitif, afektif, dan konatif. Kognitif adalah sesuatu hal yang dipercaya oleh suatu individu terhadap sikap yang dimilikinya. Kognitif ini lebih mengarah pada suatu masalah yang menjadi kontroversial. Afektif adalah suatu perasaan yang mengarah pada aspek emosional.

\section{c. Gambaran Peran orang tua siswa terhadap perilaku mencuci tangan menggunakan sabun di SD Negeri 08 Kota Lubuklinggau}

Berdasarkan hasil penelitian yang dilakukan oleh peneliti di SD Negeri 08 Kota Lubuklinggau dari 106 Siswa, terdapat peran orang tuatidak mendukung $(43,4 \%)$ dan peran orang tua mendukung $(56,6 \%)$.

Berdasarkan hasil penelitian yang dilakukan oleh peneliti di Gambaran peran orang tua terhadap perilaku mecuci tangan di SD Negeri 08 kota lubuklinggau. Terdapat siswa yang menyatakan bahwa orang tua tidak mendukung yaitu dengan nilai skor $0=$ tidak mendukung jika skor jawaban $<46$ median Berdasarkan hasil penelitian tersebut terdapat tidak baik 10 siswa hal ini terlihat dari hasil observasi dilapangan bahwa ada yang mengisi kuesioner mengatakan orang tua siswa tidak pernah mengingatkan mencuci tangan setelah bermain, orang tua siswa juga tidak menjelaskan tentang cara mencuci tangan yang benar, dan orang tua siswa tidak pernah mengajarkan teknik 7 langkah mencuci tangan yang baik dan benar.

Berdasarkan hasil pengamatan dari pernyataan siswa terdapat 32 siswa yang menyatakan peran orang tua yang mendukung dalam perilaku mencuci tangan menggunakan sabun hal ini terlihat orang tua siswa menjelaskan tentang pengertian mencuci tangan, orang tua mereka mengingatkan tentang bahaya jika tidak mencuci tangan. 
Penerapan perilaku hidup sehat tidak hanya melibatkan peran sekolah saja yang berpengaruh, tetapi peran-peran orang tua sangat dibutuhkan agar pengetahuan siswa tentang perilaku hidup bersih dan sehat menjadi lebih tinggi. hal ini disebabkan orang tua merupakan pendidik pertama sehingga orang tua diharapkan memberikan arahan dan bimbingan yang baik kepada anaknya (Alif, 2014).

\section{Analisis Bivariat}

\section{a. Hubungan Pengetahuan dengan Perilaku Mencuci Tangan Menggunakan Sabun di SD Negeri 08 Kota Lubuklinggau}

Berdasarkan hasil uji statistik ChiSquare menunjukkan bahwa ada hubungan yang signifikan antara pengetahuan dengan perilaku mencuci tangan menggunakan sabun di SD Negeri 08 Kota Lubuklinggau dengan keeratan hubungan di kategorikan lemah artinya ada faktor lain yang bisa menyebabkan terjadinya perilaku mencuci tangan menggunakan sabun di SD negeri 08 Kota Lubuklinggau.

Hasil penelitian ini sejalan dengan Penelitian yang dilakukan Zuraidah (2013) di Kota Lubuk Linggau tentang hubungan pengetahuandengan Perilaku Cuci Tangan Pakai Sabun yang benar pada siswa kelas V SDIT AN-NIDA menunjukkan adanya hubungan signifikan antara pengetahuan dengan perilaku mencuci tangan. Sejalan juga dengan Khoirudin et.al (2015) menyimpulkan bahwa terdapat hubungan antara tingkat pengetahuan dengan sikap cuci tangan sebelum dan setelah makan pakai sabun pada siswa kelas 4, 5, 6 SDN Ngebel Tamantirta Kasihan, Bantul. Hasil Penelitian ini juga sejalan dengan penelitian yang dilakukan Nugroho \& Fajriyah (2014). Pada murid kelas III dan IV SD Negeri 21 Talang Kelapa Kabupaten Banyuasin diketahui ada hubungan yang bermakna antara pengetahuan terhadap penerapan cuci tangan pakai sabun. Menurut teori bloom mengungkapkan bahwa domain penting untuk terbentuknya tindakan dan penerimaan perilaku baru yang berlandaskan pengetahuan bersifat long lasting pada seseorang adalah pengetahuan. Sebaliknya, apabila perilaku itu tidak disadari oleh pengetahuan dan kesadaran akan tidak berlangsung lama. Perbandingan dengan teori rogers, yang menyebutkan bahwa orang yang sudah tahu (awarenes) terhadap suatu hal belum tentu dia akan berperilaku yang benar sebelum yang bersangkutan melakukan beberapa tahap sampai pada akhirnya dia mengadopsi hal tersebut dengan tepat (Gracia, 2015).

\section{b. Hubungan Sikap dengan Menggunakan Sabun dengan Perilaku mencuci tangan menggunakan sabun di SD Negeri 08 Kota Lubuklinggau}

Berdasarkan hasil uji statistik ChiSquare menunjukkan bahwa tidak ada hubungan yang signifikan antara sikap dengan perilaku mencuci tangan menggunakan sabun. Artinya sikap bukan merupakan faktor yang dapat mempengaruhi perilaku siswa di SD Negeri 08 Kota Lubuklinggau

Hasil penelitian ini sejalan dengan penelitian yang dilakukan oleh Waruwu (2018) pada siswa SD Swasta Al Ulum Kecamatan Medan Area dari hasil penelitiannya di dapatkan bahwa tidak terdapat hubungan antara sikap dengan perilaku Cuci tangan pakai sabun pada siswa SD Swasta Al ulum Kecamatan Medan area. Penelitian lainnya juga dilakukan oleh Saptianingsih (2013) menunjukkan bahwa tidak ada hubungan antara sikap dengan perilaku mencuci tangan pada anak SD Negeri 3 Kertajaya Padalarang.

Perubahan sikap seseorang melewati beberapa tahapan yaitu mulai dari menerima hingga menghayati (Notoadmojo,2007). seseorang dapat berubah sikap dan perilakunya berawal dari ia menerima informasi dan rangsangan dalam masalah, situasi maupun gejala. Setelah mendapatkan informasi, biasanya seseorang mulai mengikut sertakan dirinya dalam suatu 
masalah, sehingga ia mulai memikirkan tentang hal yang akan terjadi jika tidak melakukan suatu hal tersebut. Pada tahap akhir, seseorang akan menghayati apa dampak yang ia terima dan akan lebih mengontrol tingkah laku sehingga menjadi suatu sikap yang menetap (Budiman, 2013)

Sikap merupakan reaksi atau respons seseorang yang masih tertutup terhadap suatu stimulus atau objek. Menurut Lawrence Green, dalam Notoatmodjo (2010), dalam memberikan informasi, Sikap adalah suatu respon seseorang terhadap stimulus atau objek tertentu yang melibatkan faktor pendapa tdan emosi yang bersangkutan (senang-tidak senang, setuju- tidaksetuju, baik- tidakbaik dan sebagainya).

\section{c. Hubungan Peran Orang Tua dengan} perilaku Mencuci Tangan Menggunakan Sabun dengan Perilaku Mencuci Tangan Menggunakan Sabun di SD Negeri 08 Kota Lubuklinggau

Berdasarkan hasil uji statistik ChiSquare menunjukkan bahwa tidak ada hubungan yang signifikan antara peran orang tua dengan perilaku mencuci tangan menggunakan sabun di SD Negeri 08 Kota Lubuklinggau. Artinya peran orang tua bukan merupakan faktor yang dapat mempengaruhi perilaku siswa di SD Negeri 08 Kota Lubuklinggau.

Hasil penelitian ini sejalan dengan Penelitian yang dilakukan Mukminah, Istiarti, \& Huda (2016). Berdasarkan hasil uji statistik dengan uji chi Square menunjukkan p-value sebesar 1.000 karena p-value $>$ dari 0,05. Hal tersebut menunjukkan bahwa tidak ada hubungan antara dukungan orang tua dengan praktik cuci tangan pakai sabun pada siswa SD di wilayah kerja puskesmas banyuurip purworejo.

\section{KESIMPULAN}

1. Dari 106 siswa, terdapat 56 siswa $(52,8 \%)$ memiliki pengetahuan baik di SD Negeri 08 Kota Lubuklinggau.
2. Dari 106 siswa, terdapat 61 siswa $(57,5 \%)$ memiliki sikap favorable di SD Negeri 08 Kota Lubuklinggau.

3. Dari 106 siswa, terdapat 60 siswa (56,6\%) memiliki peran orang tua baik di SD Negeri 08 Kota Lubuklinggau.

4. Dari 106 siswa, terdapat 91 siswa ( 85,8 \%) memiliki perilaku mencuci tangan menggunakan sabun Baik di SD Negeri 08 Kota Lubuklinggau.

5. Ada hubungan yang signifikan antara pengetahuan dengan perilaku mencuci tangan menggunakan sabun di SD Negeri 08 Kota Lubuklinggau dengan kategori hubungan lemah.

6. Tidak ada hubungan yang signifikan antara sikap dengan perilaku mencuci tangan menggunakan sabun di SD Negeri 08 Kota Lubuklinggau.

7. Tidak ada hubungan antara peran orang tua dengan perilaku mencuci tangan menggunakan sabun di SD Negeri 08 Kota Lubuklinggau.

\section{SARAN}

1. Bagi SD Negeri 08

Bagi sekolah mengadakan edukasi tentang perilaku mencuci tangan yang baik dan benar dan pihak sekolah dapat meningkatkan fasilitas yang mendukung perilaku mencuci tangan.

2. Bagi peneliti Lain

Diharapkan dapat meneliti faktorfaktor lainnya yang berhubungan dengan perilaku mencuci tangan menggunakan.

\section{DAFTAR PUSTAKA}

Desiyanto, \& Djannah. (2013). Efektifitas Mencuci Tangan Menggunakan Cairan Pembersih Tangan Antiseptik (HandSanitizer) Terhadap Jumlah Angka Kuman, Jurnal Kesehatan Masyarakat, Vol. 2 No. 2.

Diana E, Budiman, Ismawati (2016) Hubungan Tingkat Pengetahuan Mencuci Tangan pada Siswa Kelas 4 
dan 5 SD Pertiwi di Kelurahan Tamansari. Prodi pendidikan dokter, fakultas kedokteran, Universitas Islam Bandung

Fewtrell, L., Kaufmann, R. B., Kay, D., Enanoria, W., Haller, L., \&Colford, J. M. (2005). Water, sanitation, and hygiene interventions to reduce diarrhoea in less developed countries: a systematic review and meta-analysis. The Lancet infectious diseases, 5(1), 42-52.

Global Hand Washing Day (GHWD2). (2008). Planners Guide. Clean Hands Save Lives. Report, $15^{\text {th }}$ October. Retrieved from:

http://www.globalhandwashingday.org/Planne rsGuide Global Handwashing Day.pdf Kemenkes RI. (2011). Pedoman Pembinaan Perilaku Hidup Bersih dan Sehat. Jakarta: Kementrian Kesehatan RI.

Kemenkes RI. (2011). Katalog Informasi Pilihan Sarana Cuci Tangan Tepat Guna. Ditjen PP- PL: Jakarta

Kemenkes RI. (2013). Riset Kesehatan Dasar (Riskesdas) 2013.Badan Penelitian dan Pengembangan Kesehatan.Kementrian Kesehatan RI, Jakarta. (2014). Perilaku Mencuci Tangan Pakai Sabun di Indonesia. Jakarta Pusat Data dan Informasi Kementerian Kesehatan RI.

Ma'rifah, A., \&Krisdian, A. (2015).Hubungan Penyuluhan Cuci Tangan Dengan Perilaku Cuci Tangan Pakai Sabun Pada Siswa Kelas 1 di SD Negeri Centong Desa Centong Kecamatan Gondang Kabupaten Mojokerto.Jurnal keperawatan sehat, 12(02).

Mukminah N, Istiarti V.G.T, dan Syamsulhuda BM. (2016).Faktor-faktor yang Berhubungan dengan Praktik Cuci Tangan pakai Sabun Pada Siswa SD di Wilayah Kerja Puskesmas Banyuurip Purwerojo. Jurnal Kesehatan Masyarakat, Vol. 4 No. 5 : 354-360.

Tahun 2016. Jurnal Kesehatan Masyarakat Khatulistiwa, Vo. 4 No. $3: 212-217$.

Notoatmodjo, S.(2007). Pendidikan Dan
Perilaku Kesehatan. Jakarta: PT. Rineka Cipta.s

Notoatmodjo, S. (2007). Promosi Kesehatan dan ilmu perilaku. Jakarta: Rineka Cipta.

Notoatmodjo, S. (2010).Metedologi peneltian kesehatan. Rineka Cipta : jakarta

Notoatmodjo, S (2010). Promosi Kesehatan Teori dan Aplikasi. Jakarta: Rineka Cipta.

Nugroho, B.S. \& Fajriyah N. (2014) FaktorFaktor yang Berhubungan dengan Penerapan Cuci Tangan Pakai Sabun pada Murid Kelas III dan IV SD Negeri 21 Talang Kelapa Kabupaten Banyuasin Tahun 2012. Jurnal Ilmu Kesehatan Masyarakat, Vol. 5 No 1 : 71-76

Mukminah N, Istiarti, V.G.T, \& Syamsulhuda, B.M. (2016) Faktor-Faktor yang berhubungan dengan praktik cuci tangan pakai sabun pada siswa sd di wilayah kerja puskesmas banyuurip purworejo.Jurnal kesehatan masyarakat (e-journal) Volume 4, nomor 5, oktober 2016 Lestari, D.(2008). 'Efektivitas Metode Expository Teaching Terhadap Perilaku Mencuci Tangan dengan Menggunakan Sabun', Skripsi, Universitas Katolik Soegijapranata

Priyoto. (2015). Nursing Intervention Classification Dalam Keperawatan Gerontik Jakarta: Salemba Medika.

Priyoto. (2015). Perubahan Dalam Perilaku Kesehatan. Yogyakarta: Graha Ilmu

Saptianingsih. (2013). Faktor-Faktor yang Berhubungan dengan Perilaku Mencuci

Tangan pada Anak Sekolah Dasar Negeri 03 Kertajaya Padalarang.Jurnal Universitas Diponegoro.

Waruwu, A.S (2018) Faktor-Faktor yang berhubungan dengan perilaku mencuci tangan pakai sabun pada siswa SD kecamatan Medan Area Tahun 2018.

Zuraidah 2013, Hubungan Pengetahuan dan Sikap dengan Perilaku Mencuci Tangan dengan benar pada siswa kelas VI SDIT AN NIDA'Kota Lubuk Linggau. ejournal.Stikesborromeus.ac.id/file diakses tgl 22 Desember 2015 